http://dx.doi.org/10.12775/RT.2020.005

\title{
Mateusz Superczyński*
}

\section{Miejskie artykuły wojskowe z lat 1607-1699 i przysięga żołnierzy toruńskich}

\author{
Municipal Military Articles from the Period 1607-1699 \\ and the Oath of Torun's Soldiers
Die städtischen Militärartikel von 1607-1699 und der Eid der Thorner Soldaten

\begin{abstract}
Streszczenie. Tekst zawiera edycję toruńskich artykułów wojskowych z lat 1607-1699, które mają charakter zarządzenia wewnętrznego i dotyczą działań żołnierzy w obrębie murów miasta. Źródło omówiono w kontekście badań nad dziejami wojskowości toruńskiej w okresie przedrozbiorowym. Zachowany przekaz źródłowy przechowywany w Archiwum Państwowym w Toruniu potwierdza dążenia władz miejskich do uregulowania kwestii związanych ze służbą żołnierzy w garnizonie miejskim oraz ukrócenia ich niezdyscyplinowania.
\end{abstract}

\begin{abstract}
The article contains an edition of Torun's military articles from the period 1607-1699, which are internal regulations and concern the activities of soldiers within the city walls. The source was discussed in the context of research on the history of Torun's military in the pre-partition period. The preserved source materials kept at the State Archives in Torun confirm the efforts

* Absolwent Uniwersytetu Mikołaja Kopernika - archiwistyki i zarządzania dokumentacją (2009-2014) oraz studiów doktoranckich w zakresie historii (2015-2019). W latach 2012-2014 pracownik Archiwum Uniwersyteckiego UMK, a od 2015 r. Archiwum Państwowego w Toruniu. ORCID: 0000-0002-8176-412X
\end{abstract}


of the municipal authorities to regulate the issues related to the service of soldiers in the municipal garrison and to curb their lack of discipline.

Zusammenfassung. Der Artikel enthält eine Edition der Militärartikel von Thorn von 1607-1699, die als interne städtische Verordnung zu verstehen sind und Aktivitäten der Soldaten innerhalb der Stadtmauern betreffen. Die Quelle wurde im Rahmen der Forschungen zur Geschichte des Thorner Militärwesens in der Zeit vor den Teilungen besprochen. Die im Staatsarchiv in Thorn aufbewahrte Quelle bestätigt die Bemühungen der Stadtbehörden, die Fragen des Dienstes der Soldaten in der städtischen Garnison zu regeln und deren Undiszipliniertheit ein Ende zu setzen.

Słowa kluczowe: wojskowość Torunia, artykuły wojskowe, źródła, edycja, Archiwum Państwowe

Keywords: Toruń's military, military articles, sources, edition, State Archive

Schlüsselwörter: Militärwesen von Thorn, Militärartikel, Quellen, Edition, Staatsarchiv

W zasobie Archiwum Państwowego w Toruniu odnaleźć można liczne przekazy źródłowe dokumentujące funkcjonowanie straży miejskiej w dawnym Toruniu, a właściwie istnienie do roku 1793 silnego garnizonu miejskiego, który podkreślał znaczącą pozycję miasta i był gwarantem jego pewnej niezależności na tle innych ośrodków w Rzeczypospolitej. Do takich źródeł zaliczyć trzeba przede wszystkim Artikelsbrieff (miejskie artykuły wojskowe) będące statutami zawodowymi dla żołnierzy miejskich.

Początki wojskowości Torunia można wiązać już z okresem średniowiecza, a dokładniej z założeniem Bractwa Strzeleckiego, które od 1352 r. było odpowiedzialne za organizację ewentualnej obrony miasta przed wrogiem. Wysiłek zbrojny Torunia widoczny był na przestrzeni wieków także w wielu konfliktach. Hanzeatyckie miasto brało udział m.in. w wyprawach na Gotlandię w 1396 r., a w czasie Wielkiej Wojny w latach 1409-1410 wystawiło swój oddział zbrojnych liczący 214 ludzi, który walczył podczas bitwy pod Grunwaldem. Pierwsze oddziały wojska zawodowego powołano w Toruniu w czasie wojny trzyna- 
stoletniej. W dokumentach brakuje właściwego punktu, w którym miasto uzyskało prawo posiadania własnego wojska. Początki istnienia regulacji prawnych określających istnienie stałego garnizonu stacjonującego w mieście można wiązać z przywilejami Kazimierza Jagiellończyka dla Torunia z roku $1457^{1}$, jednakże w samym dokumencie brakuje wyraźnej informacji o zniesieniu obowiązku kwaterunku wojska królewskiego i „prawa załogi” (ius praesidii) ${ }^{2}$. Możliwe, że formuła potwierdzenia dawnych przywilejów przez króla oraz wysoka pozycja, jaką Toruń uzyskał w drodze inkorporacji, umożliwiła miastu interpretację zapisów na korzyść zachowania własnych oddziałów wojskowych $^{3}$. W kolejnych stuleciach miasto rozwijało swoją obronność, między innymi rozbudowując fortyfikacje i unowocześniając je na wzór zachodnich umocnień typu holenderskiego ${ }^{4}$. Toruń posiadał także arsenał oraz odwach, czyli kwatery zawodowego wojska miejskiego. Żołnierze toruńscy, służący zarówno pieszo, jak i konno, mieli na swoim wyposażeniu jednolite mundury oraz uzbrojenie w postaci broni palnej (muszkiety). Należy dodać, że organizacja obrony miasta oparta była na podziale obszaru zabudowy miejskiej na kwartały. W obrębie murów miejskich było 7 kwartałów (Świętojański, Starotoruński, Mariacki, Chełmiński, św. Mikołaja, Sukienniczy, św. Jakuba), do których przydzielono osobne oddziały - kompanie z własnymi chorągwiami o różnych barwach. Prezentowane w artykule źródło podaje, że w skład oddziałów wojskowych zorganizowanych przy kwartałach wchodzili podoficerowie (Unteroffizieres) jako kaprale (Korporals) oraz rotmistrzowie jazdy (Rottmeister). Kwartały przedmiejskie prawdopodobnie nie posiadały swoich chorągwi, choć ich organizacja mogła również wynikać z funkcji obronnych oraz konieczności zachowania bezpieczeństwa w razie pożaru ${ }^{5}$. Sprawy wojskowe nadzorowała Rada Miej-

\footnotetext{
${ }^{1}$ Archiwum Państwowe w Toruniu (dalej cyt. APT), Akta miasta Torunia, Katalog I, dokumenty i listy, sygn. 1754.

${ }^{2}$ M. Biskup, U schylku średniowiecza $i$ w początkach odrodzenia (1454-1548), [w:] Historia Torunia, t. 2, cz. 1, pod red. M. Biskupa, Torun 1992, s. 8-60.

${ }^{3}$ Acten der Ständetage Preußens, hrsg v. M. Toeppen, Bd. 4, 1884, nr 385-387.

${ }^{4}$ B. Dybaś, Dzieje wojskowe Torunia w latach 1548-1660, [w:] Historia Torunia, t. 2, cz. 2, pod red. M. Biskupa, Toruń 1994, s. 141-154.

5 Ibid., s. 142; M. Superczyński, Wilkierz dla przedmieść Torunia z 1637 roku, Rocznik Toruński, t. 44, 2017, s. 85-110.
} 
ska wespół z burgrabią. Być może na czas zagrożenia wojennego organizowano radę wojenną, podobnie jak w przypadku Gdańska, jednakże brakuje przekazów źródłowych potwierdzających to przypuszczenie $^{6}$.

Oprócz wspomnianego „prawa załogi” (ius praesidii) ważnym elementem obronności miasta Torunia był nadzór nad stanem fortyfikacji miejskich (ius fortalicii). W myśl dokumentu Zygmunta III z 1523 r., regulującego organizacje ustroju miasta (tzw. „Reformatio Sigismundi”), utrzymanie fortyfikacji w należytym stanie było obowiązkiem Rady Miejskiej. W dokumencie wskazano także na konieczność posiadania przez urząd budowlany stałych środków na renowację umocnień i murów miejskich ${ }^{7}$.

Funkcjonowanie stałego garnizonu wynikające z obowiązku dbania o bezpieczeństwo miasta we własnym zakresie powodowało konieczność wydawania odpowiednich ustaw radzieckich, które regulowały sferę związaną z obronnością miasta.

Dotychczas nie analizowano dokładnie przepisów wydawanych przez Radę Miejską dla straży i wojska toruńskiego. W literaturze dotyczącej wojskowości Torunia skupiano się w dużej mierze na twierdzy toruńskiej i jej nowożytnych fortyfikacjach, choć poruszano także wątki dotyczące garnizonu miejskiego ${ }^{8}$. Miejskie artykuły wojskowe

${ }^{6} \mathrm{~K}$. Łopatecki, Miejskie artykuły wojskowe w nowożytnej Europie - zarys problematyki, Miscellanea Historico-Iuridica, 2016, t. XV, z. 1, s. 68.

7 APT, Akta miasta Torunia, Katalog I, dokumenty i listy, sygn. 2943; Dybaś, Dzieje wojskowe Torunia, s. 143.

${ }^{8}$ B. Dybaś, Między niezależnościa a podporzadkowaniem. Przemiany w statusie militarnym wielkich miast Prus Królewskich w XVII i XVIII wieku, Zapiski Historyczne, t. 65, 2000, z. 2, s. 57-75; tenże, Miasto jako twierdza. Garnizony w miastach Rzeczypospolitej polsko-litewskiej w XVII wieku, Czasy Nowożytne, t. XIII, 2002, s. 125 135, tenże, Die Stadt als Festung-Garnisonen in den Städten der polnisch-litauischen Rzeczpospolita im 17. Jahrhundert, [w:] Historia Urbana, Tomul VIII, 2000/1-2, Bucuresti 2003, s. 31-40; tenże, Militarne funkcje i znaczenie miast środkowoeuropejskich w średniowieczu i czasach nowożytnych, [w:] Miasta i mieszczaństwo w Europie Środkowowschodniej do połowy XIX wieku, red. D. Michaluk, K. Mikulski, Torun 2003, s. 55-69; M. Giętkowski, Twierdza Toruń i jej garnizon do 1815 r., [w:] Militaria pomorskie: zbiór studiów, t. 4, Bydgoszcz 2012, s. 8-28; B. Dybaś, Burmistrz i budowniczy. Henryk Stroband i Antoni van Obberghen wobec budowy fortyfikacji w Toruniu w końcu XVI wieku, [w:] Piśmienność pragmatyczna - edytorstwo źródel historycz- 
poddane zostały analizie i badaniom w przypadku Rygi oraz Gdańska ${ }^{9}$. Autor tekstów omówił znaczenie tego typu zarządzeń miejskich, wskazując między innymi, że do artykułów wojskowych dołączano zazwyczaj teksty przysięgi żołnierzy (przykład Gdańska). Artykuły ryskie z 1600 r. miały jednak odmienny charakter od innych tego typu aktów $\mathrm{z}$ racji bliskości zagrożenia wojennego $\mathrm{w}$ tym czasie i statusu miasta, które w następnych latach opierało się atakom szwedzkiej armii w trakcie zmagań o Inflanty w latach 1600-1611.

Najstarsze wojskowe ustawy miejskie w Toruniu mogły być ogłaszane już w XVI w., choć nie ma na to dowodów w przekazach źródłowych. W Gdańsku pierwsze takie akty były wystawiane przez kondotierów i dowódców oddziałów zaciężnych, a następnie aprobowane przez Radę. Dopiero w 1. połowie XVII w. uregulowano sprawy prawne, kiedy to Rada zaczęła uchwalać własne zarządzenia. Mogło to mieć związek z koniecznością zwiększania liczebności zbrojnych ze względu na zagrożenie szwedzkie $\mathrm{w}$ tym czasie $^{10}$. Podobnie w Toruniu wydanie niektórych zarządzeń wojskowych przez władze miejskie miało ścisły związek z zagrożeniem szwedzkim w 1629 r. ${ }^{11}$ Znane są także kolejne rozporządzenia miejskie z 1652 i 1655 r., które ukazały się drukiem ${ }^{12}$. Szczególnie druga ordynacja mogła być odpowiedzią na atak Szwecji na Rzeczpospolitą.

Toruńskie artykuły wojskowe, których edycję i thumaczenie zawiera niniejszy tekst, pochodzą jednak z wcześniejszego okresu, a dokładnie z 8 października $1607 \mathrm{r}$. Odnowione i zaktualizowane zostały z kolei w 1699 r. ${ }^{13}$ Liczą łącznie 35 punktów, po nich zaś na końcu zapisano przysięgę żołnierzy składaną Radzie Miejskiej w języku niemieckim

nych - archiwistyka. Studia ofiarowane Profesorowi Januszowi Tandeckiemu w sześćdziesiąta piąta rocznicę urodzin, red. R. Czaja, K. Kopiński, Toruń 2015, s. 609-647.

${ }^{9} \mathrm{~K}$. Łopatecki, Charakterystyka miejskich artykułów wojskowych na przykładzie „Regischer Artikelsbrieff" z 1600 r., Zapiski Historyczne, t. 78, 2013, z. 2, s. 5-37; tenże, Miejskie artykuły wojskowe w nowożytnej Europie.

${ }^{10} \mathrm{~K}$. Łopatecki, Charakterystyka miejskich artykułów wojskowych, s. 7-8.

${ }^{11}$ J. E. Wernicke, Geschichte Thorns aus Urkunden, Dokumenten und Handschriften, Bd. 2: Die Jahre 1531-1840 umfassend, Thorn 1842, s. 219-221; B. Dybaś, Dzieje wojskowe Torunia., s. 151.

12 Ordnung der Bürgerwache, Thorn 1652; Ordnung für die Bürger Thorns zur Müsterung, Thorn 1655.

${ }^{13}$ APT, Akta miasta Torunia, akta luźne, sygn. 7319. 
lub polskim. Ponieważ artykuły zostały opublikowane w okresie pokoju i braku zagrożenia zewnętrznego dla miasta $\mathrm{w}$ tym czasie, nie zawierają punktów dotyczących współdziałania oddziałów toruńskich np. z wojskiem koronnym czy dowodzenia w czasie wojny. Mają one raczej charakter aktu regulującego funkcjonowanie straży miejskiej i garnizonu $\mathrm{w}$ czasie pokoju $\mathrm{w}$ mieście. Artykuły miały na celu przede wszystkim zwiększenie zależności oficerów od Rady Miejskiej i wymuszenie ich bezwzględnego posłuszeństwa, a także ukrócenie samowoli niektórych strażników miejskich, którzy, jak czytamy we wstępie, popełniali wiele nieprawidłowości i występków. Wśród tych przewinień pojawiają się pijaństwo, rozbój, przesypianie warty, faworyzowanie niektórych podkomendnych przez oficerów oraz korupcja. Dokument wskazywał także na obowiązki żołnierzy i wartowników oraz regulował kwestie związane $\mathrm{z}$ wypłacaniem żołdu. W przeciwieństwie do innych znanych tego typu zarządzeń, wydawanych przez rajców np. miasta Rygi, artykuły toruńskie nie ustalały dokładnie sposobu zaciągu żołnierzy. Brakuje w nich punktów dotyczących organizacji regimentu, choć w teście aktu wymienieni są: Hauptmann, Rottmeister (rotmistrz), Korporal (kapral) czy profos. Można jednak dostrzec parę podobieństw do artykułów ryskich, jak choćby mało skonkretyzowane rodzaje kar wymierzanych krnąbrnym i nieposłusznym żołnierzom. Było to zazwyczaj ogólnikowe określenie kar „na ciele, na życiu”. W paru przypadkach pojawia się pokuta „o chlebie i wodzie” lub ,zakucie w żelazo" (kajdany?) i więzienie (art. 1) ${ }^{14}$. Inną karą przewidzianą za kilkakrotne przewinienia, np. przychodzenie na służbę w stanie upojenia, było wyrzucenie żołnierza z kompanii (art. 7). Artykuły toruńskie wykazują pewne podobieństwo do regulacji gdańskich z 1646 r., które wydano pod tytułem Der Stadt Dantzigk Kriegs-Artickel für ihre Vnterhaltene Soldaten zu Ross und Fuss ${ }^{15}$. Nieco krótsze, bo liczące 21 punktów, choć bardziej szczegółowe, artykuły gdańskie wskazywały na obowiązek utrzymania broni $\mathrm{w}$ dobrym stanie, wymieniały wiele

\footnotetext{
${ }^{14}$ Por. też: K. Łopatecki, Charakterystyka miejskich artykułów wojskowych, s. 23.

${ }^{15}$ Der Stadt Dantzigk Kriegs-Artickel für ihre Vnterhaltene Soldaten zu Ross und fuss verfasset im Anfang des Jahres 1646, [w:] W. Hahlweg, Das Kriegswesen der Stadt Danzig: durch eine Einführung und einen Dokumenten-Anhang erweiterter Neudruck der Ausgabe Berlin 1937, Bd. 1, Das Kriegswesen der Stadt Danzig: Die Grundzüge der Danziger Wehrverfassung 1454-1793, Osnabrück 1982, s. 17-24.
} 
kar za różne przestępstwa popełniane przez żołnierzy oraz wskazywały na ich obowiązki. W przeciwieństwie do aktu wydanego przez władze Torunia w bardziej szczegółowy sposób opisywały organizację wojska, dowodzenie itp. ${ }^{16}$

Na końcu tekstu artykułów toruńskich, podobnie jak w przypadku regulacji wydanych przez Radę Miejską w Gdańsku, umieszczono treść przysięgi żołnierskiej w językach niemieckim i polskim. Żołnierze, zarówno piesi, jak i konni, ślubowali posłuszeństwo przede wszystkim Radzie Miejskiej, co znaczyło, że nie są najemnikami, lecz zawodowym wojskiem podległym wyłącznie władzom miasta. W przysiędze jest także mowa o działaniach zarówno w obrębie murów miejskich, jak i poza nimi w przypadku zagrożenia wojennego z zewnątrz. W obu tekstach przysięgi nieco odmienne brzmienie mają kończące ją formuły. W wersji niemieckiej jest to: „So wahr als uns Gott Helfe, und sein Heiliger Wort”, a w polskiej: „tak nam Panie Boże dopomóż i niewinna Męka Syna Jego". Może to sugerować względy religijne, a więc służbę żołnierzy wyznania luterańskiego i katolickiego.

\section{MIEJSKIE ARTYKUŁY WOJSKOWE Z LAT 1607-1699 I PRZYSIĘGA ŻOŁNIERZY TORUŃSKICH ${ }^{17}$}

Archiwum Państwowe w Toruniu, Akta luźne, sygn. 7322. Przekaz $w$ formie poszytu z kartonowa okładka barwioną. Źródto $w$ dobrym stanie, pismo czytelne, kancelaryjne, brak oryginalnej foliacji. Teksty przysięgi zredagowane inna ręka niż pozostałe artykuty. Przepisy prawne wydzielone za pomoca numeracji. Na oktadce niebieska kredka zapisany tytut: Wach Ordnung 1607 (1699). Tekst liczacy 16 stron jest oryginatem zredagowanym $w$ momencie wydania rozszerzonego aktu w 1699 r. Zachowaty się późniejsze odpisy artykułów w liczbie trzech egzemplarzy, prawdopodobnie z początku XVIII w. (sygn. 7319-7321), na co wskazuje ręka pisarza. Elementem późniejszym, z 1. połowy XVIII w., dodanym do oryginatu, jest thumaczenie przysieggi żotnierskiej na język polski, na co wskazuje dukt. Edycja tekstu miejskich artykułów wojskowych z lat 1607-1699 została przygotowana zgodnie z instruk-

\footnotetext{
${ }^{16} \mathrm{~K}$. Łopatecki, Miejskie artykuły wojskowe w nowożytnej Europie, s. 68-70.

${ }^{17}$ APT, Akta miasta Torunia, akta luźne, sygn. 7322.
} 
cją wydawnicza K. Lepszego dla źródet historycznych od XVI do potowy XIX w. ${ }^{18}$ oraz wskazówkami J. Schultzego ${ }^{19}$, stad też ortografię i pisownię zarówno w języku niemieckim, jak i polskim uwspółcześniono. Skrócenia rozwiazano bez zaznaczania w tekście.

[s. 2]

BESTALLUNG DER SOLDATEN ODER
WACHORDNUNG UND ARTIKELSBRIEF AUFFGERICHTET
UND VERBESSERT DEN 8. MONATS TAG OCTOBRIS
ANNO 1607
UND WIEDERUMS AUFS NEUE VERMEHRET
UND VERBESSERT ANNO 1699

[s. 3] Dennach bei ${ }^{a}$ täglicher Erfahrung befunden wird, dass viel und mannigfältiget Unordnungen, unter den Soldaten sind stehen, die zu Grossen Schaden der Stadt und Wach teil der Regierung derselben gereichen, gleich wohl aber nicht allenthalben der Gebühr nach abgestrafft werden, die weils auf solche und dergleichen Stück keine gewisse Ordnung oder Artikels Brieff sind auf gerichtet worden: Als hat Ersamen Edelichen Ehrenwesen Hoch-Wohlweisen Rath auf Gutt achten Verordnet und beschlossen, dass nach folgende Ordnungen oder Artikels Brief von alle dem Krieges Volke[?], so in ihre Diensten ist, von Punkt zu Punkt gehalten und denselbigen folge geleistet werde, zu welchen Ende solche Artikels Brieff, alle Jahr zum zum Wenigsten sechsmal denen Soldaten sollen vorgelesen werden, damit der unerfahrne Soldat, sich mit der Unwissenheit nicht wird können entschuldigen, sich auch vor Schaden wird Wissen zu Hütten.

$\mathrm{Zu}$ Wissen sei männiglichen, dass ein Edeliche Eherrliche Hoch-und Wohlweisen Rath, dieser Stadt, aus allerhand vorgehenden reiften bedrucken seine gewisse Soldaten Bestallung Wach-Ordnung Artikels Brieff beliebet und geschlossen, deren man sich künftig in aller zu

${ }^{18}$ Instrukcja wydawnicza dla źródet historycznych od XVI do połowy XIX wieku, red. K. Lepszy, Wrocław 1953.

${ }^{19} \mathrm{~J}$. Schultze, Richtlinien für die äussere textgestaltung bei der Herausgabe von Quellen zur neueren deutsche Geschichte, Blätter für deutsche Landesgeschichte, $\mathrm{Bd}$. 98 (1962), s. 1-11.

${ }^{a} \mathrm{U}$ góry strony cztery gwiazdki narysowane tuszem. 
stehen den Gefahr// [s. 4] so wohl vor Fremde, als Bürger und Einwohner binnen und außerhalb der Stadt, zu gebrauchen habe, wie hier unten in beschriebene Artikeln folget:

1.

Erstlichen sollen die Verordnete und beeidigste Soldaten sämtlich und ein jeder, in sonderheit des Fluchens Schwerens: und dergleichen Miss brauchs Göttlich Namens sich enthaltend, bei höher Straffe denn wer den Namen des Herren lestert, der sol zum ersten mahl in die Eisen geschlagen, und mit Wasser und Brodt gesteiset werden, Tut er es zum andern mahl soll ihm seine Zeuge mit einen glienden Eise durch stahen werden, und biss aufs Hembd auss gezogen, und aus unsern Land schaffen verbannet werden.

\section{2.}

Ein jeder soll schuldig sein einen Ersamen Rath und den vorgesetzten Wach Herren, und nach dem selben ihren vorgesetzten Offizieren und befehls Habern, gehorsam Treu und Holt sein, und wass Ersamen Erbaren Rath durch solche läst befehlen wegen gemeiner Stadt dasselbige sollen, die Soldaten, getreulich ausrichten und mit ganzen Fleiss ins Wercke stellen.

\section{3.}

Alles was vermerkt wird, dass wieder Ersamen Erbaren Rath vor der Stadt sein möchte, dass soll ein jeder schuldig sein getreulich und unverzöglich dem verordneten Wach Herren, oder denen Offizieren zu offen bahren.//

4.

[s. 5] Es soll ein jeder seine Rüstung, ober und unter Gewehr, sambt aller zugehörung auf allen fall zu jeder Zeit bei der Hand und fertig haben, die selbigen nicht versetzen, oder verpfänden, auch nicht verleichen, auch Kraft und Loth nicht unmütze vershiessen, auch soll sichkeiner unterstehen in der Stadt es sei bei Tage oder Nacht vielweniger auf den Schildwachten einiges Geschoss ab zu shiessen oder sonsten einigen Allarm zu machen. Wann es die hohe Notdurft nicht erfordert bei höher Straffe. 


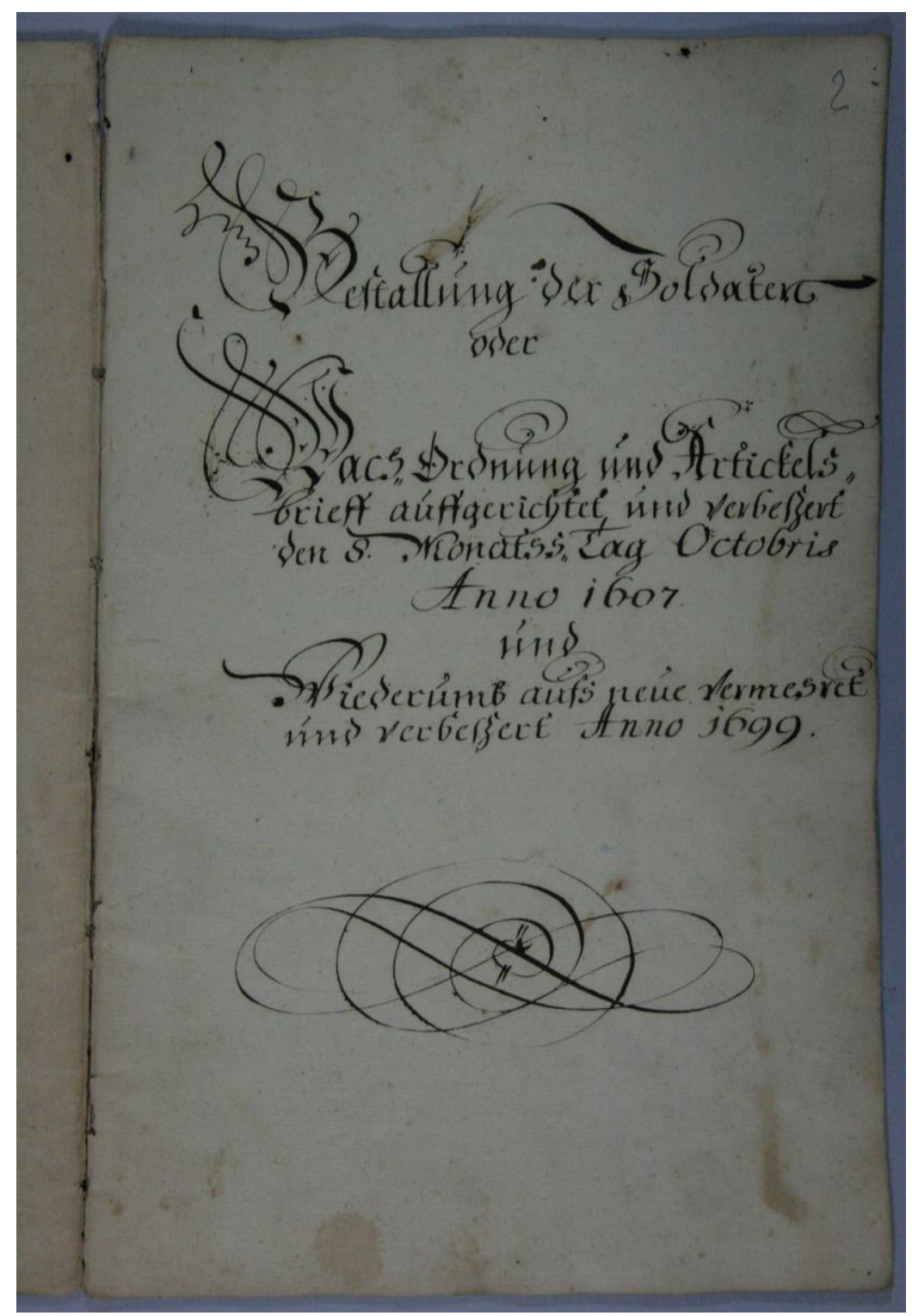

Strona tytułowa toruńskich artykułów wojskowych 
5.

Ein jeder soll schuldig sein, bei Tag und Nacht fleissig Wache zuhalten, ab sonderlich an denen Stadt Tohren keine verdächtige Personen durch zulassen, auch sich von seinen verordneten Offizieren auf und ab führen zulassen, wie es zu jeder Zeit die Gelegenheit und noch erfordert, und ihm befohlen, wird auch von sich selbsten, nicht abgehen, er habe dem dessen Urlaub, bei schwerer verleibes Straff.

6.

Die Soldaten, wenn die Zeit davon ist, und sich zu ordentlicher Wache einige stellet, sollen alle ihren Gedank, dahin richten, damit bei Tag und Nacht auch[?] und Fried erhalten, damit die gemeine Bürgerschaft auch fremde Leute, reichend Arm sammt den Ihriegen in ihren Häusern und Herberge// [s. 6] sicher und ruhig sein und blieben mögen.

7.

Wer trunken auf die Wach komt oder woll auf derselben betroffen wird also dass er die Wacht nicht nach Notdurft versehen kann der soll also Bald mit dem Eisen Gestrafft werden thut er solches zum andern, oder dritten Mal soll er auss der Compagnie ausgemusterten den, und ohne abschied von der Compagnie verstossen werden

\section{8.}

Wer auf der Schildwach sich nieder setzt oder schläft gehet auch woll gar Ehend[?] zu vor ab, ehe er abgelöset wird der soll am Erben gestrafft werden. Dieser Artikel erfordert von einer Schildwacht dreierlei. Ersten: dass er auf der Schildwacht nicht nieder sitze ${ }^{b}$ denn auf das sitzen folget das schlafen zum $^{\mathrm{b}}$ andern, dass sie nicht schlaff, denn die Schildwacht ist Auge der ganzen Stadt, und wäre gar unterantwortlich, dass durch eines Menschen Unachtsamkeit eine ganze Stadt umbleib und leben gutt und Blut oder durch früers Gefahr, oder andern Unfall solte gerathem, würde sichs aber zutragen, dass unser Stadt solte durch eine solche unachtsame Schildwacht Schaden zugefügt werden, solte solche ohne alle Gnad am Erben gestrafft werden.

b-b Fragment dopisany na marginesie. 
9.

Wenn die Thor- oder Wach Glock umb Seigen 9 gelautet wird, und darauf die zehende Stunde, vorüber, soll nichts Desto weniger jeder Mann, der// [s. 7] mit einer Lichte oder Licht friedlich seinen Weg zu Woll ziehen verstattet werden, es wäre denn dass eine vor dächtige Person wäre, die etwa Schaden machen kann, als am Zeughauss Stadt Thor Krambuden unter dem Rathhaus oder Kellern, Kram Laden auf den Marckt und Gassen. Durch sein heimlich schleichen sich vor Dächtig machet, die oder denselbe soll mit aller bescheidenheit darum zur Wede gestellet werden. Wird aber an solchen etwas vermerkt sollen sein die Verwahrung genommen werden.

10.

Die jenigen, welche des Abends und Nachts Zeiten nicht der Musik über die Gassen gehen, da sie sich friedlich verhalten, mächten, sollen, von der Wach um angefachten bleiben, die Spielleute aber, in gute Obacht genommen und dem Wach Herren angezeiget werden, damit solche der wegen zur Straffe werden gezogen.

11.

Belanget die Nachtraben und Umblätter so auf den Gassen den Leuten die Fenster ausswerfen, oder in die Steinhause, Tisch, Schragen, Wagen, Wässer, Weinkrantz, Bierkegel umstoßen, oder zerbrechen, und andere Uppigkeiten trieben, schreien, juchzen, schießen, alle die jenigen, es sei zu was Zeiten es wolle, wenn um die Wacht an ihr Amt getreten ist// [s. 8] Nota bene soll die Wach solche Nachtraben, samt den Stielleuten, auf heben in ordentliche Verwahrung nehmen oder Narren Häusslein einsperren, und es auf folgen den Morgen an die Wachherren gelangen lassen, doch soll sich die Wache hierbei der Schläge und übermässigen gewalt enthalten, es sei demm dass sich femand zur Wehre setzet, und also Uhr solche da zu geben würde, doch soll hierumme der beste Glimpft und Bescheidenheit gebraucht worden. 
12.

Betreffend die von adliche[?] ist hierbei auf weierlei Ding Acht zugeben, nemlich, dass sie sich besonderlich des Nachts entweder stille und friedlich auf der Gasse verhalten, oder wem sie zum Tummelt gewalt thut, Schlägerei und auflauff Uhr sach geben, auf denersten fall, wenn sie sich friedlich verhalten, es sei um ohne, oder mit der Musik, es sei zu welcher Zeit des Nachts es wolle sollen die Wachen oder Schildwachen, unangestrachen Passiren lassen, und nicht die geringste Uhr sachgeben.

13.

Was die fremde Adelschaft oder ohre Diener ambelanget, es sei zu Abends Zeiten, oder in der Nacht, und sie sich unrichtig verhalten auf öffentlichen Marckt und Gassen, oder in Häussern und herbergen jemands aus// [s.9] frewel aufhallen, Fagen Schlagen, Laternen oder Kannen, oder andere Sachen aussreissen, oder den Leuten auf ihre Häusser schiessen und dergleiche unerträtglichen wieder Willen und gewalt sich unter füngen, daselbst soll der Wachmeister mit etlichen Soldaten anselbige Leute mit allen Bescheidenheit sich verfügen, und von solchen Frewel und gewalt abmachen mit solchen Worten, wenn ihnen was unrecht wiederfahren, in Name Ersamen Erbaren Raths billig Gerechtigkeit zu sagen und vor dieses mahl sich zu ruhe begeben, wolten mus aber dieses alles nicht verschlagen, soll der Wachmeister, oder Hauptmann, wo es von Nöthen mehr Soldaten zu sich fordere, und solchen gewalt Thätern ihre wehre abnehmen, und ohne Gewehr in ihre Herberg gehen würden sich aber solche dieses Wegern, und darüber zur wehr setzen, da auch die Soldaten oder andere dabei ihres eigene lebens in Gefahr gerathen solten, so ist natürlichen Rechtens, dass sich ein jeder da in seinen Beruf und Station aufs wehre und sich nicht Schlagen lasse, sondern Gewalt mit Gewalt abtriebe.

14.

Benendlichen aber, da bei Nachtzeiten etwas ein Bürger, oder der Stadt Einwohner, oder aber Fremde Leute, sei im Haus oder auf öffentlichen Strassen verwundet oder gar entliebet würde, oder es auch einen Soldaten begeneter solches soll umgesamt den Wach Herren angemeldet, 
und von ihnen er// [s. 10] warten, wie sich weiter zu verhalten, in dessen aber den Thäter mit Bescheidenheit in das Wachhaus gebracht und daselbst in guter verwahrsamkeit gehalten werden.

15 .

Begebe es sich, dass vor einen Bürger ${ }^{\mathrm{c}}$ sein Haus bei Nachtzeiten, von jemande gestürmet, oder mit hauen Werffen, schiessen, oder auf zu lauffen unter derselbe ${ }^{\mathrm{d}}$ soll auf friescher Tat, darübergriffe, in die Varwahrung genommen werden, und oben gemelden Wach Herren angemeldet werden.

16.

In solchen und dergleichen Gewalts fälten soll gleich wohl das wach Haus nicht ganz ledig gelassen werden, sondern mit etlichen Soldaten besetzet bleiben.

17.

Weillen es sich ofters begiebet, dass die Gäste sowohl in Bier auch Wein Kälssern und Kellern, in und aus erhalb den Jahrmarkt, wie auch ihren Herbergen allerlei Unfug, Hader und Balgen anfangen und anrichten, da durch die Bürger oder Wirt, wenn sie von ihren Person nicht rathen können, dass sie Wach müssen fordern lassen, als soll solche Forderung der Wach den abnwesenden Hauptmann oder Wachmeister vermeldet, den Hader und das Schlagen mit beschiedenheit zu verwehren, und denschuldigen mit sich in die Verwahrung nehmen, und den folgenden Tag dem Wach Herren anmelden.

18 und 19.

Die Thurn Wächter, welche des Nachts einige Stunden verschlaffen, darauf die Soldaten sonderlig die zu Nachts Zeite auf ihren Posten stehen, gutt Acht haben// [s.11] sollen bei ihren Eid und befehlen, und solches den Wach Herren an gezeiget wen den, damit der Wächter mit Gefängniss gestraff werden soll.

\footnotetext{
${ }^{\mathrm{c}}$ Wyraz nadpisany u góry.

' Obok, na marginesie, dopisany wyraz „tünde”.
} 
20.

Wenn, da Gott von sei, heuer aus kommt, es sei in oder auserhalb der Stadt, so balt von Soldaten was vermerkt, sollen selbegleich stehendes Husses den Wach Herren ankündigen, die andern aber so kein Wach haben, sollen ungesambt mit ihren Ober- und Unter Gewehr sich von das Wach Hauss einfinden und daselbst ihres befehls gewärtig sein. Wird aber einer oder der andere in solchen fällen säumig sein, die oder derselbe soll Schwere Straff gewärtig sein.

21.

Da einer oder der andere von unserer Soldateschka bei besetzter Wach oder umbe setzer Wache, oder in seinen oder andere Logement gegen Ersamen Erbaren Rath oder gemeinen Ruhestand der Stadt sich mit gefährlichen oder unzeiemlichen Worten vernehmen liess, oder sonst zur unruh Ursache gebe, der soll vor eine Meutmacher[?] gehalten, und nach gebühr ernstlich gestraff werden, uns sollen die andern Knecht so solches hören schuldig sein, an zu zeigen, bei verlust ihres ehrlichen Namens.

22.

Wenn es Noth wäre, dass die Soldaten alle samtlich oder Rotten Weise in - oder ausser der Stadt oder zu beschützung derrer land gutter oder andern örther verschäckt würden, sollen sie sich keines weges Wegern sondern alle Zeit freiwillig und getreulich sich gebrauchen lassen als Ehrliebende// [s. 12] Soldaten gehört und wohl ansehet, und sich keines weges Wegern.

23.

Ein jedweder, er sei Offiziere oder gemeiner Soldat soll sich des Spielens und wollsauffens, auch zutrinkens enthalten, viel weniger einige um Trunke nöthigen, bei Schwerer leibes Straffe begebe es sich aber dass einer in Woller Weiss muss handelt, und sich mit der Trunckheit wolte entschuldigen, der oder die selben sollen desto harter gestrafft werden. 
24.

Das aus fondern und Balgen soll gäntzlich und durch aus verbothen sein, sondern der Soldat, welche mit Worten oder Wercken zu viel geshen ist, soll sich zu dem Hauptmann verfügen derselbe soll, nach dem Er alle beide Parthen angehört, dass demselben welchen Unrecht geshehen, vom dem andern mit Blossen Haupt, in gegen Wort der Wollen Wach ein abtrag geschehe, und sie sich mit ein ander vergleichen wollen sie es nicht thun, soll solches denen Wach Herren angezeiget werden, und als dann Grösserer Straff gewärtig sein.

25.

Wann der Profoss, oder seine Leut einen oder mehr gefänglich an nohmen, so soll sie niemand daran hindern, oder sich dessen annehmen, würde aber einer oder der andere so Kühn sein, ihm einen solchen gefangenen auss den Händen zu Weisse, der soll am Leib, oder an seinen Ehren gestrafft worden.//

26.

Es soll auch ein jeder sein Ober- und Untergewehr in guter Acht haben, solches nicht werderben, sein Weg werffen, oder versetzen auch nicht verpfländen sondern alle Zeit bei sich tragen, damit er sich dessen als ein Krieges Mann noth dürfflich kann gebrauch auch ohne Kraut und Loth sich einmahls finden lassen, werder wieder thut soll mit ernstlicher Straffe angesehen werden.

27.

Es soll auch ein jeder in friedes, Gefahr und Nöthen auf Befehl des Hauptmann oder andere Befehlshabern zur Arbeit oder Hauen nebenst der Bürgerschaft ohne einige wieder Rede, sich gutt Willig gebrauchen lassen, bei ihren Eid und Pflichten.

28.

Es soll auch keiner ohne Verlaub muss von der Wache weg gehen, auch keiner keinen Wachter an seine Stell stellen, ohne Consens des Offizieres, es sollen die Rottgesellen solches bei ihren Jurament schuldig sein anzuzeigen, es soll auch ein jeder gutte Achtung geben auf die 
Losung, so ihm gegeben wird, welcher aber der Losung vergessen wird, oder mit einer unrechten Losung befunden wird, der soll vor Recht gestellet werden, und nach Erläutniss desselben entweder an Ehe oder am Leib gestrafft werden.

29.

Und so nun der Hauptmann, oder ein anderer kommandirte Offizier führ sich, oder durch seine Befehls haben jemands umb seinen Ungehorsam, oder Verbrechens Wegen wolte in verhafft oder unter die Wach nehmen oder auch sonsten straffen lassen, soll sie niemand// [s. 14] daran hindern, oder da wieder rathen, vielweniger mit Worten, oder mit der Tat sich gegen sie vergreifen, bei höher Leibes Straffe.

30.

Wegen der Unteroffizieres als Korporals, gefreiters Rottmeisters soll es also gehalten werden, wen dieselbe shenähet, oder sich ihres Amts Kommando entgegen setzet oder selbige mit der Haust bedrauen wird zzu schlagen der ein Gewehr auf sie Zücken, und dessen genungsahm über Wiesen würde, dieser oder dieselben sollen entweder an Ihrer, auch wohl gar am Leben, nach Erläutniss der hohen, obrigkeit gestrafft werden.

31.

Was woll sauffen und Spiehlen der würffen und Hartes soll bei inserer Soldaten gäntzlichen verbothen sei bei Schwerer Leibes Straffe, auf das ein jeder umb so, viel länger sich zu erhalten hat, und damit nicht Ursache haben vor der Zeit umb Geld, oder Vielmehr mitihrem empfangenen Monat Sold geffansahm umb gehen und dasselbige nicht vergeben oder mutwilliger Weise vorspielen[?], oder vor schwenden, und sollen die Officiren Schuldig sein, die Recht zu jederzeit mit ganzen Ernst dazu zu vermahnen und zuhalten.

32 .

Welcher dem jenigen so durch die Wachten Passiren etwas abnimmt mit Gewalt, es sei Holz, Stroh oder andere Sachen, wie die auch Nahmen haben mögen, der soll nicht nur alleine zur wieder stattung gehal- 
ten werden, sondern auch noch mit harter Straffe erstlich angesehen werden, entweder am Leibe, oder Ehe, oder Standes Erniedrigung nach Erläutniss der hohen Obrigkeit.

33.

Alle diese Ordnung und Befehl so Ersamen Erbaren Rath, oder die verordneten Wach Herren, und der Hauptmann über diese// [s. 15] Artikel, nach Gelegenheit der Zeit auf setzen und anordnen möchten, die soll ein jeder getreulich und unversämt verrichten, und also auf nehmen, als wenn Ersamen Erbaren Rath selbsten gegenwärtig Wäre, und soll hiermit Ersamen Erbaren Rath sei stehen, diesen Artikels Brieff und Wachordnung zu mündern und zu vermehren, nach Erheischung der Notdurft und dieser Stadt Gelegenheit.

34.

Und worinner oder mehr diese Artikel nicht genungsahm vernommen hätten, die jenigen sollen sich zum Wach herren oder zu denen Offizieren verfügen und Recht bericht von ihm nehmen.

35 .

Einen jeden Soldaten soll seine Besoldung Monatlich richtig zugestellet werden, davor soll er Ersamen Erbaren Rath, so land mit Diensten verbunden sein, als mann freier wird nützlichen zugebrauchen haben begebers sich aber, dass der Monat ausswäre, und die Lehnung oder Besoldung nicht gleich so baar verhanden wäre, so sollen die Soldaten nicht desto weniger keinen Zug oder Wach, oder was ihm angemuthet wird nicht abschlagen, sondern der Bezahlung halben sich gedulden, keinen Rumor oder Aufruhr manchen, wo aber einer oder der andere dar wieder Handelte, der soll angezeiget werden, damit solcher Mitmacher zum verhafft gebracht und ernstlich gestrafft, damit gut Regiement bei um sein Krieges Volk erhalten wird, dessen will Ersamen Erbaren Rath die vorsorge thun, dass wie bissher geschehen, einen jeden richtige Bezahlung gefalle, und Niemands hierau verkürtzet werden soll.// 


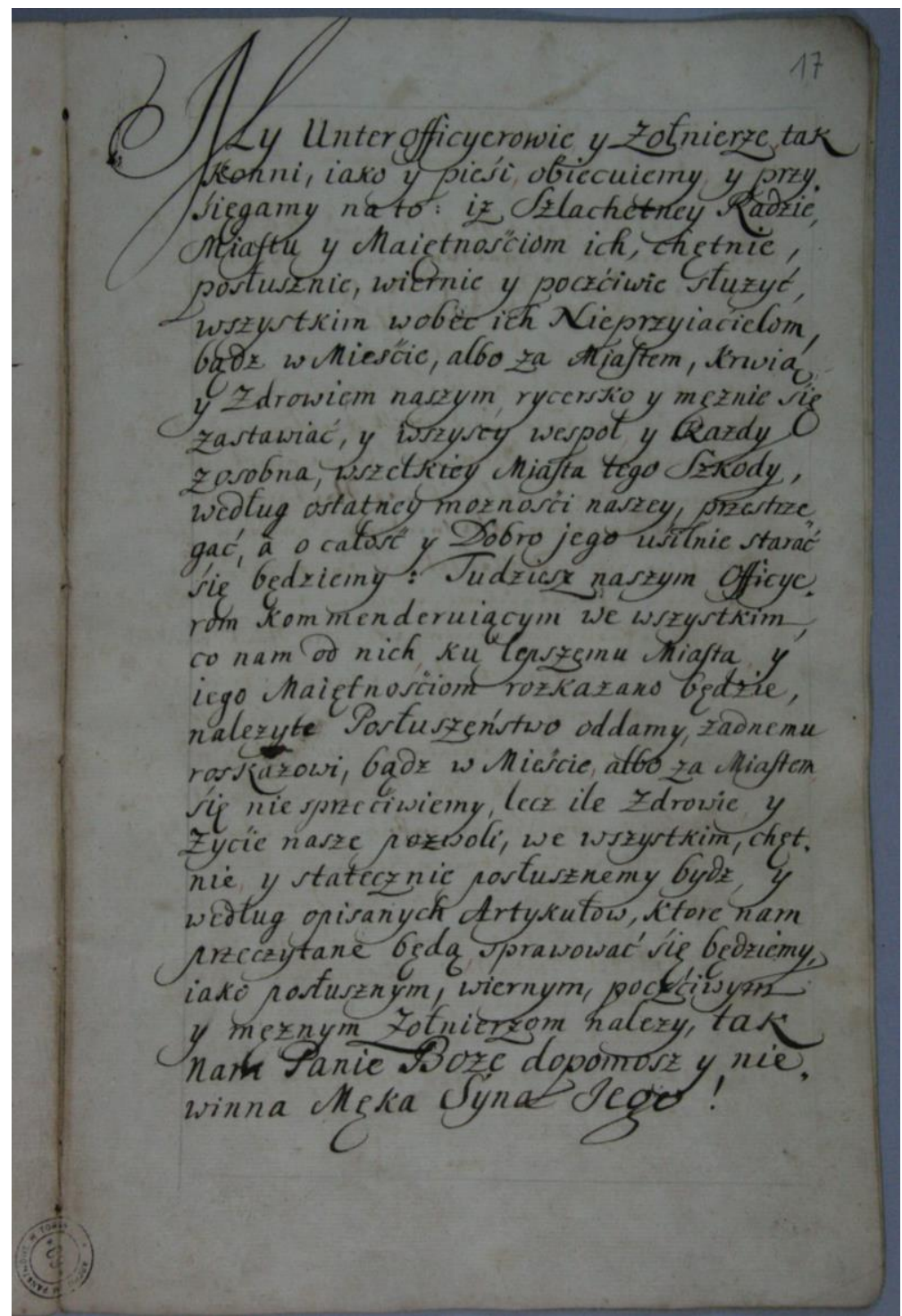

Miejskie artykuły wojskowe z lat 1607-1699. Tekst przysięgi żołnierskiej. APT, Akta miasta Torunia, akta luźne, sygn. 7322 
Wir Offizierer und Soldaten zu Ross und Fuss geloben und schweren, dass wir ein Hochedliche Rath und der Stadt auch derselben Landschafften willig, gehorsam, getreu und redlich dinnen, ihrer allerseits feinden, es sei in - oder außerhalb der Stadt, unser Leib und Blut Tapffer und Mannhaft engegen sitzen und insgesambt allen Schaden und Nachtheil der Stadt nach unsern besten Vermögen abwenden, dagegen ihren Nutzen und Wohlfahrt nussert befordere wollen. Imgleichen wollen wir unsere Befahls habern, in denen, was der Stadt und dero Landschaften besten wegen, uns von Ihnen anbefohlen wird, schuldigen gehorsam leisten, von keinem Kommando, es sei in oder außerhalb der Stadt uns entziehen sondern so lange unser Leben und Gesundheit es zulässet, demselben willig und Standhafftig folgen, auch uns sonsten nach Anleitung der Verfasseten und uns vorzulesen den Artikel, in allen also erzeigen, wir es gehorsamme, getreuen, ehrlichen uns unverzagten Soldaten und Kriegs Leuten gebühret. So wahr als uns Gott Helfe, und sein Heiliger Wort!//

[s. 17] My unteroficerowie i żołnierze tak konni, jako i piesi, obiecujemy i przysięgamy na to: iż Szlachetnej Radzie, Miastu i majętnościom ich, chętnie, posłusznie, wiernie i poczciwie służyć wszystkim wobec ich nieprzyjacielom bądź w Mieście, albo za Miastem, krwią i zdrowiem naszym rycersko i mężnie się zastawiać, i wszyscy współ i każdy z osobna, wszelkiej Miasta tego szkody, według ostatniej możności naszej, przestrzegać, a o całość i Dobro jego usilnie starać się będziemy: Tudzież naszym oficerom komenderującym we wszystkim co nam od nich ku lepszemu Miasta i jego majętnościom rozkazano będzie, należyte posłuszeństwo oddamy, żadnemu rozkazowi, bądź w Mieście, albo za Miastem, się nie sprzeciwiemy, lecz ile zdrowie i życie nasze pozwoli, we wszystkim chętnie i statecznie posłusznemi być i według opisanych Artykułów, które nam przeczytane będą, sprawować się będziemy jako posłusznym, wiernym, poczciwym i mężnym żołnierzom należy, tak nam Panie Boże dopomosz i niewinna Męka Syna Jego!// 
MIEJSKIE ARTYKUŁY WOJSKOWE Z LAT 1607-1699 I PRZYSIĘGA ŻOŁNIERZY TORUŃSKICH ${ }^{20}$

\author{
PRAWO ZAWODOWE ŻOŁNIERZY ALBO ZARZĄDZENIE \\ O STRAŻY MIEJSKIEJ ORAZ ARTYKUŁY POPRAWIONE \\ I ULEPSZONE 8 DNIA MIESIĄCA PAŹDZIERNIKA ROKU 1607 \\ I PONOWNIE NA NOWO POSZERZONE I ULEPSZONE \\ W ROKU 1699
}

Na podstawie codziennych doświadczeń stwierdzono, że wśród żołnierzy występuje wiele szkodliwego nieporządku, który jest bardzo szkodliwy dla miasta i władz straży, nie ponosząc ponadto żadnej odpowiedzialności w postaci kar, czego powodem jest brak konkretnych zarządzeń, jak i ordynacji, jaką szacowna, czcigodna i wielce znamienita Rada dla dobrego poszanowania zarządza i postanawia, że według następujących zarządzeń i artykułów o wszystkich wojskowych, a więc o ich służbie, od punku do punktu mają być zachowane i tak samo wykonywane, do których końca taki artykuł, każdego roku, co najmniej sześciokrotnie powinien być czytany żołnierzom, tak aby niedoświadczony żołnierz nie mógł się usprawiedliwić niewiedzą, także dla szkody.

Do wiadomości wszystkich bez wyjątku szacowna i wielce znamienita wysoka Rada tegoż miasta na podstawie wcześniejszych rozmaitych doświadczeń wydaje dla swoich żołnierzy artykuły prawa - zarządzenia straży miejskiej postanawiając i publikując, aby w przyszłości kierowali się oni wszelkim zagrożeniem, a także, aby zarówno obcy, jak i obywatele oraz mieszkańcy miasta i przedmieść korzystali z niżej następująco zapisanych artykułów:

Po pierwsze, powinno się zarządzić, że wszyscy zaprzysiężeni żołnierze, którzy we własnej osobie popełniają ciężkie przewinienia i w taki sam sposób nadużywają Imienia Bożego, powinni zostać ukarani $\mathrm{z}$ wielką stanowczością i wysoką karą w Imię Pana, przy pierwszym razie powinno się ukarać poprzez zakucie w żelazo i trzymanie o chle-

${ }^{20}$ APT, Akta miasta Torunia, akta luźne, sygn. 7322. 
bie i wodzie, jeśli zaś uczyniłby to ktoś kolejny raz pod świadkiem, powinien zostać ukarany poprzez skucie żelazem i wygnanie z naszego kraju.

\section{2.}

Każdy powinien być posłuszny szacownej Radzie i zwierzchnictwu, a tym samym przełożonym i dowódcom, być posłusznym, wiernym i dumnym, a także kierować się pożyteczną radą poprzez wykonywanie rozkazów dla całego miasta. Żołnierz powinien wiernie wykonywać rozkazy i odznaczać się doskonałą starannością w pracy.

\section{3.}

Wszystko, co zostało zapisane, co ponownie szacowna i czcigodna Rada chce dla miasta, powinien każdy być temu wierny i powinno to być przekazane dowódcom straży oraz oficerom, aby to zachowywali.

\section{4.}

Każdy powinien mieć swój rynsztunek do dyspozycji przez cały czas i być pod swoim karabinem, którego pod żadnym względem nie można zostawić oraz pod żadnym pozorem nie może być bez powodu wykorzystany oraz nikt nie powinien $\mathrm{w}$ mieście $\mathrm{w}$ dzień czy $\mathrm{w}$ nocy, na warcie, niepotrzebnie strzelać, aby nie wzbudzać niepotrzebnego niepokoju lub w inny sposób nie sprawiać kłopotów, gdy nie wymaga tego wyższa konieczność, pod groźbą wysokiej kary.

5.

Każdy powinien być czujny podczas warty w dzień i w nocy, zwłaszcza przy bramach miejskich, po to, aby nie pozwolić na wpuszczenie żadnych podejrzanych osób, a także powinien być kierowany przez przydzielonego mu oficera, jak i nie powinien nigdy przy żadnej sposobności i bez konieczności odchodzić bez rozkazu, pod groźbą kary, chyba że ma pozwolenie.

6.

Kiedy żołnierze w odpowiednim czasie są przydzielanie do odpowiedniej warty, powinni cały swój umysł pokierować zarówno w dzień, jak i w nocy tak, aby utrzymywać pokój, po to, aby obywatelom miasta, 
jak i ludziom obcym zapewnić spokój i bezpieczeństwo, tak w swoich domach, jak i w miejscu schronienia, pozostawiając ich w spokoju i bezpieczeństwie.

\section{7.}

Jeśli ktoś przychodzi na wartę pijany lub miał taki zamiar i nie chciał pełnić straży bez usprawiedliwienia, powinien takowy zostać natychmiast złapany i ukarany żelazem, a jeśli czyniłby to kolejny i trzeci raz, należy go wydalić z kompanii i bez dymisji wygonić.

\section{8.}

Ktokolwiek siedzi lub śpi na warcie, powinien także udać się do przełożonego, zanim zostanie zwolniony i winien ponieść stosowną karę. Ten artykuł wymaga od strażnika warty trzech rzeczy. Po pierwsze: że nie siedzi na warcie i że nie śpi, gdyż wartownik jest okiem całego miasta $\mathrm{i}$ byłby nawet odpowiedzialny za utratę całego miasta przez swoje niedbalstwo oraz utratę życia i krwi, lub też jakieś inne niebezpieczeństwo i inny popełniony wypadek, a dowodziłoby to, że nasze miasto zostało poszkodowane przez tak nieumyślnego wartownika i powinien on zostać sprawiedliwie ukarany bez pobłażania.

\section{9.}

Kiedy dzwon na bramie lub strażniczy wybije dziewięć razy, a następnie minie godzina dziesiąta, każdy człowiek ze światłem lub bez może pokojowo przedostać się do miasta, chyba że będzie to osoba podejrzana, która może wyrządzić szkodę w arsenale miasta, bramach, budach, kramach pod ratuszem lub w piwnicach, kramach na rynku i ulicach. Potajemnie skradających się, czyniących coś podejrzanie należy z całą stanowczością schwytać, a jeśli takie rzeczy zostaną stwierdzone, należy czynić nad nimi nadzór.

10.

$\mathrm{Ci}$, którzy wieczorem i w nocy chodzą po ulicach z muzyką, powinni zostać zatrzymani i natychmiast postawieni przed strażą, takim graj- 
kom należy zwrócić uwagę i donieść o tym przełożonym straży, którzy wskazanych ludzi stanowczo ukarzą.

11.

Należy pociągnąć do odpowiedzialności dopuszczających się nocnego rabunku i ludzi wyrzucających przez okna na ulice lub w kamienicach roztrzaskujących stoły, ościeżnice, wozy, wodę, wino, kufle od piwa, wywracających lub czyniących inne zbytki, hałasujących i krzyczących oraz strzelających, każdego, który by w tym czasie to czynił, straż powinna doprowadzić do urzędu. Ważne jest też to, aby straż takich nocnych awanturników wraz z grajkami przepisowo kontrolowała lub zamykała przybytki głupiej rozrywki. Następnego ranka należy ich doprowadzić do dowódców straży, jednakże strażnik powinien się powstrzymać od bicia i nadmiernej przemocy, chyba że ktoś przez cały czas stawiałby opór, należy jednakże z zasady stosować łagodność i powściągliwość.

12.

Jeśli chodzi o młodzieńców, należy uważać na wszystko, a mianowicie na to, że zachowują się cicho i spokojnie na ulicy w nocy, lub z początku czynią przemoc, walcząc na pięści i przeklinając. Jeśli zachowają się spokojnie, niezależnie od tego, czy to z muzyką, czy bez niej, o każdej porze nocy, strażnicy lub zbrojni wartownicy powinni podejść do nich, zanim bezkarnie ujdą lub ominą ich w krótkim czasie.

13.

Jeśli chodzi o obcych ludzi lub służących, dzieje się to wieczorem lub $\mathrm{w}$ nocy, kiedy zachowują się niewłaściwie na publicznych placach i w zaułkach lub nawiedzają się nawzajem $w$ domach i kwaterach, uderzając i wyrywając latarnie lub niszcząc dzbany i inne rzeczy, strzelając do ludzi w ich domach i dopuszczając się tym samym nikczemnych czynów i przemocy, tam też straż ma pozbyć się takich ludzi ze stanowczością i takich przestępców stanowczo słowami pouczyć, jeśli wyrządzili coś złego, by oznajmić o słusznej sprawiedliwość w imieniu szacownej i czcigodnej Rady, należy przywrócić spokój, gdyby zaś stróż lub kapitan z konieczności wymagał większej liczby żołnierzy 
w celu obrony przed tak gwałtownymi ludźmi, należy udać się do ich stanowiska $\mathrm{z}$ bronią, aby się przed nimi bronić, ponieważ żołnierze lub inni nie powinni narażać swojego życia, naturalne jest, że każdy z nich powinien bronić się na swoim posterunku i stanowisku i nie dać się pobić, ale przemoc siłą zwalczyć.

14.

W przypadku, gdyby w nocy jakiś obywatel, mieszkaniec miasta lub osoba obca w swoim domu lub na publicznej ulicy został ranny lub nieprzytomny, powinien zostać zabrany przez żołnierza, który powinien o tym zameldować swojemu dowódcy straży, a następnie sprawdzić, kto jest sprawcą, a poszkodowanego trzymać pod dobrą opieką w wartowni.

15.

Kiedy zdarzy się, że przed domem obywatela w nocy ktoś dobija się lub strzela, bije lub atakuje, należy takowego powstrzymać od rabunku i powinien on zostać zabrany do wartowni pod nadzorem.

16.

W takich i innych niebezpiecznych przypadkach nie należy pozostawiać obudzonego domu w spokoju, lecz obstawić dom przez wielu żołnierzy.

17.

Często zdarza się, że goście, zarówno spożywając piwo, jak i wino w piwnicach, na jarmarku oraz w różnego rodzaju zajazdach sprawiają mieszkańcom wiele kłopotów i wszelkiego rodzaju psikusów, na które skarżą się zarówno obywatele, jak i gospodarze, nie mogąc nic poradzić, wówczas powinni zostać wezwani strażnicy zgłoszeni przez nieobecnego kapitana lub strażnika, którzy rozwiążą problemy siłą oraz skrupulatnie zabiorą winne osoby do aresztu, a następnego dnia zameldują dowódcy straży.

\section{8 i 19.}

Strażnicy wież, którzy w nocy przesypiają kilka godzin, powinni zostać wskazani przez żołnierzy stojących w nocy na swoich posterun- 
kach, którzy mają dobre baczenie i którzy powinni przestrzegać przysięgi oraz nakazać takim ludziom zgłosić się do przełożonego straży w celu ich ukarania.

20.

Jeśli, jak Bóg da, w danym dniu danego roku, ktoś przychodzi do miasta lub wyjeżdża $\mathrm{z}$ niego, prędko powinno to być odnotowane przez żołnierzy, a następnie mają oni samodzielnie zgłosić dowódcy straży, a inni niech będą postawieni w czujności pod bronią, aby zaprowadzić takich ludzi do wartowni i być tam nawet przy dowództwie. Ale jeśli jeden lub drugi okaże się przestępcą, powinni zostać surowo ukarani.

21.

Niejednokrotnie jeden albo drugi z naszego żołdactwa na obsadzonej warcie lub straży tylnej, albo w innym miejscu, przeciwko szacownej i czcigodnej Radzie lub będąc w stanie spoczynku ujawnia się w mieście niebezpiecznymi lub niekorzystnymi słowami, albo też prowokuje do niepokoju, pozwalając, aby odbył się bunt, a po tak poważnych występkach także pozostali słudzy są często tak samo winni z powodu utraty ich uczciwego imienia.

22.

Gdyby żołnierze splądrowali lub zdewastowali w całości lub część miasta lub tereny poza nim, albo w celu ochrony swojej ziemi albo mieszkańców, nie powinni odchodzić, gdyż w dobrej wierze i wiernie wykorzystali to honorowo. Żołnierze ci powinni być wysłuchani i należy na nich dobrze patrzeć i w żadnym wypadku nie odrzucać ich.

23.

Każdy, kto jest oficerem lub zwykłym żołnierzem, powinien powstrzymać się od hazardu i picia, tym bardziej picia alkoholu, ale w przypadku silnego napięcia fizycznego konieczne jest działanie siłą woli, a w przypadku popełnionego pijaństwa przeprosiny za zuchwalstwo i tak samo poniesienie ciężkiej kary. 
24.

Wyróżnianie i faworyzowanie powinno być absolutnie zabronione, jednakże żołnierz, który słowem i pracą wyróżnia się, powinien mieć tego samego kapitana, który powinien wysłuchać obu stron, także o tym, czy czynił jakieś nieprawidłowości, od innego przeciw woli słowu straży, a jeśli tego nie uczyni powinien zostać wskazany dowódcy straży, a następnie surowo ukarany.

25 .

Kiedy profos albo jego ludzie przyjmą jednego lub więcej, nikt nie powinien powstrzymywać ich, tak żeby nie przyjęto żadnego, nawet mężnego, w przeciwnym wypadku należy takowego uwięzić i ukarać na ciele lub czci.

26.

Każdy powinien dobrze obchodzić się ze swoją bronią, nie wyrzucając jej albo przenosząc, lecz trzymać i nosić przy sobie cały czas, aby jako wojskowy mógł w razie potrzeby użycia także bez problemu odnaleźć, kto zaś czyni inaczej, podlegać będzie surowej karze.

27.

Należy pozwolić wszystkim w spokoju, jak i w niebezpieczeństwie i potrzebie, na polecenie kapitana lub innych dowódców, pracować dla obywateli bez zbędnych słów, czynić to dobrze i chętnie, pod przysięgą i z obowiązku.

28.

Nikt nie powinien odejść bez rozkazu straży, nikt nie powinien zmieniać swojego miejsca posterunku bez zgody oficerów, strażnicy powinni zadeklarować to pod przysięgą, powinni także być winni każdemu należnego szacunku, a także dla hasła, jeśli zostanie mu dane, w przypadku, gdy hasło zostanie zignorowane, zapomniane lub gdy użyje niepoprawnego, należy go zgodnie z prawem ukarać na czci lub na ciele. 
29.

A jeśli kapitan lub inny dowódca sam dowodzi, lub jeśli jego rozkaz spowodował nieposłuszeństwo lub inne zbrodnie, zostanie on aresztowany, umieszczony pod strażą lub w inny sposób uwięziony, tak aby nikt nie otrzymał błędnych rozkazów, a tym samym tymi słowami nie przyczynił się do złych czynów i zbrodni, po czym zostanie surowo ukarany na ciele.

30.

W sprawie podoficerów jako kaprali, rotmistrzów jazdy, należy zatrzymać tych, którzy okryli się hańbą, lub sprzeciwiając się dowództwu tym samym odmówili wykonania polecenia lub zniszczyli broń, co wystarczy, aby zostali sprawiedliwie i surowo, zgodnie z władzami zwierzchnimi ukarani.

31.

To, co uznaje się za pijaństwo, gry, złodziejstwo i inne poważne przewinienia, powinno być u naszych żołnierzy całkowicie zabronione pod groźbą ciężkiej kary, a z powodu takich ciężkich przestępstw, które każdy z nich może popełniać dłuższy czas, nie ma powodu, aby przed czasem wydawać pieniądze, aby z otrzymanym miesięcznym żołdem takowy nie poszedł na marnotrawstwo i aby nie wydał umyślnie na granie, a oficerowie winni są to kontrolować i zachowywać to $z$ najwyższą powagą prawa przez cały czas.

32.

Kto przepuszcza przez straż ludzi, wymuszając coś siłą, pobierając trochę drewna, słomy lub innych rzeczy, które mogą również zabierać, takich należy nie tylko zatrzymać, aby nie czynili tego ponownie, lecz także najpierw $\mathrm{z}$ całą stanowczością ukarać albo na ciele, albo na godności, lub też postawić $\mathrm{w}$ stan upokorzenia zgodnie $\mathrm{z}$ dekretem wyższych władz zwierzchnich.

33.

Wszystkich tych zarządzeń i nakazów, zarówno Szacownej i Czcigodnej Rady, jak i zarządzonych przez dowódców straży i kapitanów sto- 
jących pod nimi, należy przestrzegać i egzekwować stosownie do okazji, których każdy powinien wiernie i bez wahania wykonywać, a zatem przyjąć w takim brzmieniu, w jakim wydała obecna Szacowna i Czcigodna Rada, a tym samym, aby zapewnić Szacowną Radę, że artykuły, listy i zarządzenie straży będą ogłaszane i wykonane ze względu na potrzeby i sprawy miasta.

34.

Ci, którzy nie słyszeli o tych artykułach, powinni się o nich dowiedzieć od swoich oficerów, którzy powinni zarządzić, aby je odczytali i zgodnie $\mathrm{z}$ prawem zachowywali.

35.

Każdy żołnierz powinien otrzymać swoją pensję zgodnie z prawem, do tego powinien on szacownej i czcigodnej Radzie, jak i też swojemu krajowi dobrze służyć, aby móc swobodnie korzystać z miesięcznego żołdu, a pensja powinna być wypłacana natychmiastowo, więc żołnierze nie powinni uchylać się od warty ani czegokolwiek, czego się od nich oczekuje, lecz oczekiwać na zapłatę, nie czyniąc przy tym plotek ani zamieszek, ale w przypadku, gdyby jeden lub drugi czynił to ponownie, należy to zgłosić, aby taki przestępca został postawiony przed sądem i surowo ukarany, a także, by w czasie działań wojennych był utrzymany dobry regiment, a szacowna i czcigodna Rada powinna upewnić się i dokonać wszelkich właściwych płatności, aby nikogo nie pominąć.

\section{Bibliografia}

Źródła rękopiśmienne

Archiwum Panstwowe w Toruniu, Akta miasta Torunia, Katalog I, dokumenty i listy, sygn. 1754.

Archiwum Państwowe w Toruniu, Akta miasta Torunia, akta luźne, sygn. $7319,7320,7321,7322$.

Dokumenty wydane drukiem

Acten der Ständetage Preußens, hrsg v. M. Toeppen, Bd. 4, 1884, nr 385-387.

Ordnung der Bürgerwache, Thorn 1652.

Ordnung für die Bürger Thorns zur Müsterung, Thorn 1655. 


\section{Literatura}

Biskup M., U schyłku średniowiecza i w poczatkach odrodzenia (1454-1548), [w:] Historia Torunia, t. 2, cz. 1, red. M. Biskup, Toruń 1992, s. 8-60.

Dybaś B., Burmistrz i budowniczy. Henryk Stroband i Antoni van Obberghen wobec budowy fortyfikacji w Toruniu w końcu XVI wieku, [w:] Piśmienność pragmatyczna - edytorstwo źródel historycznych - archiwistyka. Studia ofiarowane Profesorowi Januszowi Tandeckiemu w sześćdziesiąta piatą rocznicę urodzin, red. R. Czaja, K. Kopiński, Toruń 2015, s. 609-647.

Dybaś B., Die Stadt als Festung-Garnisonen in den Städten der polnischlitauischen Rzeczpospolita im 17. Jahrhundert, [w:] Historia Urbana, Tomul VIII, 2000/1-2, Bucuresti 2003, s. 31-40.

Dybaś B., Dzieje wojskowe Torunia w latach 1548-1660, [w:] Historia Torunia, t. 2, cz. 2, red. M. Biskup, Toruń 1994, s. 141-154.

Dybaś B., Miasto jako twierdza. Garnizony w miastach Rzeczypospolitej polsko-litewskiej w XVII wieku, Czasy Nowożytne, t. XIII, 2002, s. 125135.

Dybaś B., Między niezależnościa a podporządkowaniem. Przemiany w statusie militarnym wielkich miast Prus Królewskich w XVII i XVIII wieku, Zapiski Historyczne, t. 65, 2000, z. 2, s. 57-75.

Dybaś B., Militarne funkcje $i$ znaczenie miast środkowoeuropejskich $w$ średniowieczu i czasach nowożytnych, [w:] Miasta i mieszczaństwo w Europie Środkowowschodniej do połowy XIX wieku, red. D. Michaluk, K. Mikulski, Toruń 2003, s. 55-69.

Giętkowski M., Twierdza Toruń i jej garnizon do 1815 r., [w:] Militaria pomorskie: zbiór studiów, t. 4, Bydgoszcz 2012, s. 8-28.

Hahlweg W., Das Kriegswesen der Stadt Danzig: durch eine Einführung und einen Dokumenten-Anhang erweiterter Neudruck der Ausgabe Berlin 1937, Bd. 1, Das Kriegswesen der Stadt Danzig: Die Grundzüge der Danziger Wehrverfassung 1454-1793, Osnabrück 1982.

Instrukcja wydawnicza dla źródel historycznych od XVI do połowy XIX wieku, red. K. Lepszy, Wrocław 1953.

Łopatecki K., Charakterystyka miejskich artykutów wojskowych na przykładzie ,Regischer Artikelsbrieff” z 1600 r., Zapiski Historyczne, t. 78, 2013, z. 2, s. 5-37.

Łopatecki K., Miejskie artykuły wojskowe w nowożytnej Europie - zarys problematyki, Miscellanea Historico-Iuridica, 2016, t. XV, z. 1, s. 59-84.

Schultze J., Richtlinien für die äussere textgestaltung bei der Herausgabe von Quellen zur neueren deutsche Geschichte, Blätter für deutsche Landesgeschihte, Bd. 98 (1962), s. 1-11. 
Superczyński M., Wilkierz dla przedmieść Torunia z 1637 roku, Rocznik Toruński, t. 44, 2017, s. 85-110.

Wernicke J. E., Geschichte Thorns aus Urkunden, Dokumenten und Handschriften, Bd. 2: Die Jahre 1531-1840 umfassend, Thorn 1842, s. 219-221. 